\title{
HAMANNOVA METAKRITIKA K PURISMU ROZUMU
}

Dílo německého myslitele Johanna Georga Hamanna (1730-1788) není zatím v českém prostředí příliš známé. Pozornost si však zaslouží jak z historických, tak systematických důvodů: Hamann na jedné straně významně ovlivnil řadu svých současníků, na druhé straně sám zpracoval řadu klíčových problémů a témat.

Jedním problémem, kterému se Hamann věnoval po celý život, je vztah rozumu a řeči. Své celoživotní úvahy k tomuto tématu shrnul roku $1784 \mathrm{v}$ textu, který je nyní $\mathrm{k}$ dispozici také v českém překladu. ${ }^{1}$ Př́ślušný text nebyl za Hamannova života nikdy publikován; koloval v rukopisných variantách a opisech. Poprvé byl uveřejněn teprve dvanáct let po Hamannově smrti v antologii Mancherley zur Geschichte der metacritischen Invasion (V̌̌elicos k dějinám metakritické invaze) ${ }^{2}$ která přinášela výběr dokumentů a materiálů $\mathrm{k}$ dobové diskusi nad kontroverzním Herderovým spisem Eine Metakritik zur Kritik der reinen Vernunft ${ }^{3}$ (Metakritika ke Kritice čistého rozumu) z roku 1799, jenž byl polemicky namîren proti Kantovi a jeho kritické filosofii.

Roku 1828 byl text převzat do první, roku 1951 do druhé souborné edice Hamannových sebraných spisů. ${ }^{4}$ Pokaždé však pod jiným názvem. Poprvé pod názvem Metakritik über den Purismus der reinen Vernunft (Metakritika k purismu čistého rozumu), podruhé pod názvem Metakritik über den Purismus der Vernunft (Metakritika k purismu rozumu). Rukopis textu se nedochoval, takže autenticitu názvu nelze př́imo ověrit. V korespondenci s Herderem a Jacobim zmiňuje Hamann obě varianty.

Jediné dva dochované opisy textu shodně potvrzují pouze druhou variantu názvu. Ve prospěch této varianty dále svědčí i formální a věcné

1 Viz str. 115-121 v tomto čísle časopisu.

2 Mancherley zur Geschichte der metacritischen Invasion. Nebst einem Fragment einer älteren Metacritik von Johann George Hamann, genannt der Magus in Norden, und einigen Aufsätzen, die kantische Philosophie betreffend, vyd. F. T. Rink, Königsberg 1800, str. 120 nn.

3 J. G. Herder, Werke, VIII, vyd. H. I. Irmscher, Frankfurt a M. 1998, str. 303 nn.

4 J. G. Hamann, Hammans Schriften, VII, vyd. G. A. Wiener, Berlin - Leipzig 1828, str. 1 nn.; J. G. Hamann, Sämtliche Werke, III, vyd. J. Nadler, Wien 1951, str. $281 \mathrm{nn}$. 
nedostatky varianty první. Formální nedostatek první varianty spočívá v tom, že obsahuje nadbytečný pleonasmus (hovoří se o purismu čistého rozumu). Jejím věcným nedostatkem je to, že obsahuje přímý odkaz na Kantovu Kritiku čistého rozumu, který je však v daném případě zavádějící. Sugeruje totiž dojem, že se Hamann v textu zaměřuje pouze na výklad a kritiku Kantova hlavního programového spisu, což ale učinil již dříve v recenzi z roku 1781. Ve skutečnosti zde Hamann spíše v návaznosti na Kanta a starší tradici formuluje vlastní - metakritické - stanovisko $\mathrm{k}$ problematice rozumu a řeči. Zaměření textu, který není pouhou reakcí na Kantovu kritickou filosofii, ale spíše nárysem Hamannovy vlastní metakritické filosofie rozumu a řeči, ${ }^{5}$ tedy věcně odpovídá spíše druhá než první varianta jeho názvu.

Východiskem nastíněné Hamannovy metakritické filosofie je základní přesvědčení o principiální jednotě rozumu a řeči. Řeč podle Hamanna není pouze prostředkem, ale také podmínkou rozumu. Toto přesvědčení Hamann vyjadřuje různě. Nejpregnantnější, a proto také nejznámější a nejcitovanější Hamannovo vyjádření se nachází v dopise Herderovi z roku 1784. V tomto dopise Hamann formuluje následující tezi: „Vernunft ist Sprache“ (,rozum je řeč“). ${ }^{6} \mathrm{Z}$ tohoto hlediska, tzn. s ohledem k původní jednotě rozumu a řeči, pak Hamann přistupuje jak ke kritice Kanta, tak ke kritice starší filosofické tradice. Na příkladu Kantovy kritické filosofie tedy pouze demonstruje obecnější systematický a historický problém rozumového purismu: snahu o očištění a oddělení rozumu od tradice, zkušenosti a řeči. Hamannova Metakritika k purismu rozumu proto není jen významným př́spěvkem k diskusi o Kantově kritické filosofii, ale také k diskusi o dějinách evropské filosofie. ${ }^{7}$

Robin Pech

5 H. A. Salmony, Johann Georg Hamanns metakritische Philosophie, Basel 1958, str. 203.

6 J. G. Hamann, Briefwechsel, V, vyd. W. Ziesemer - A. Henkel, Frankfurt a M. 1965, str. 177.

7 Srv. P.-L. Oesterreich, Podoby veřejného rozumu. Filozofičtí učitelé v prostoru politiky, přel. M. Pokorný - P. Rezek, Praha 2013, str. 54-55. - Překlad a komentář k Hamannovu textu vznikl v rámci zastřešujícího projektu „Krize racionality a moderní myšlení“, projektu „Politická a rétorická dimenze Kantovy kritické filosofie“ ř řěeného na Filozofické fakultě Univerzity Karlovy z prostředků Specifického vysokoškolského výzkumu na rok 2018. 